\title{
EME
}

ERDÉLYI TUDOMÁNYOS FÜZETEK

167. sz.

ERDÉLY TELEPÜLÉSTÖRTÉNETÉNEK VÁZLATA

SZENT ISTVÁN KORÁIG

\author{
IRTA \\ LÁSZLÓ GYULA
}

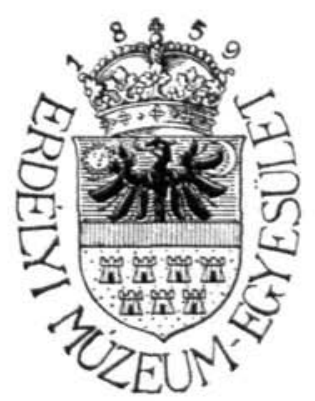

KOLOZSVÁR, 1943

AZ ERDELYI MỨZEUM-EGYESULETKIADÁSA 
Különlenyomat

aZ ERDELYI MÚZEUM

1943. évi 3-4. számából
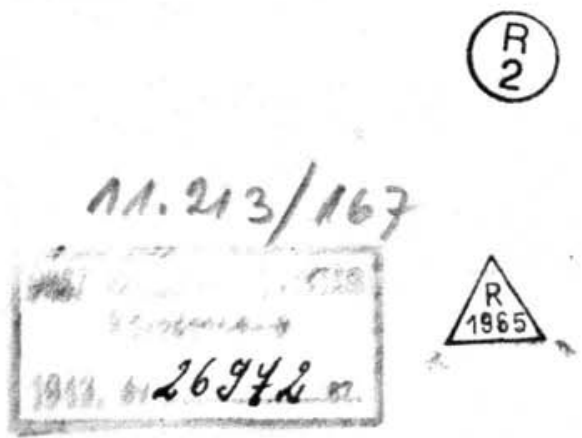

Felelōs kiadó : Lászlo Gyula 


\section{Erdély településtörténetének vázlata Szent István koráig}

1.

Az öskori s rómaikori leletek, nemkülönben a népvándorláskor emlékei gyakran erdőfödte területekröl kerülnek elö. Néha meg olyan, ma megmüvelt földön találjuk a történelemelötti idők emlékeit, ahol néhány századdal ezelött kétségkívül erdő volt még. Erdély középkori s újabbkori településének kibontakozása során igen jól megfigyelhető, hogy a földmüvelés és az egyre szélesebb területeket követelö népszaporodás miként szorítja mind feljebb és feljebb az erdöhatárt. Az egykor összefüggö erdőt először irtványok szaggatják meg, majd az irtványok mind nagyobb területekre terjeszkedve összeérnek s közöttük már csak foltok jelzik az egykori egységes erdőtakarót. Mind az okleveles adatok, határjárások és összeírások, mind pedig a dülőnevek és az erdőt járó emberek sok olyan településröl adnak hírt, amelyek területét ma ismét visszafoglalta az erdö. Az Árpádok és az Anjouk hatalmának hanyatlása után Erdélyt rengeteg dúlás érte $s$ ennek következtében nagy területek néptelenedtek el. Egyrészüket ma sem hódította még vissza az ember. Magam is jártam például Erdővidéken Dobó és Volál községek erdőboritotta területén (Erdőfüle és Magyarhermány között). A figyelmes szemlélö elött még ma is szinte zavartalanul rajzolódik ki a rengeteg fái alatt az egykori falu. A magyar régészetnek elsőrangứ kötelessége lenne a magyar nép életének e jelentős emlékeit — a középkori magyar falvakat - feltárni. Sajnos ezen a téren szégyenletesen keveset tettünk eddig. Györffy István volt itt is a kezdeményező, Szabó Kálmán pedig a Kecskemét környéki falvak feltárásával szerzett örökbecsü érdemeket. Ha ehhez még egy két újabb ásatást hozzáveszünk, már el is soroltuk mindazt, ami eddig történt. Erdélyben Pósta Béla iskolájának nagyjelentőségü kezdeményezése után csupán az Erdélyi Tudományos Intézet és a Székely Nemzeti Múzeum munkatervében folytatódik a munka $\mathrm{s}$ a kidei térségben végzett középkori ásatások már is jelentős eredményekkel gazdagitották adattárunkat. $\mathrm{E}$ tervezett $\mathrm{s}$ részben már meg is valósított munkának célja nemcsak az egykori állapotok emlékanyagának feltárása, hanem ezen túlmenöleg az embernek a földért vívott harcára is fényt szeretne deriteni.

Az Alföldön ez a harc a víz, a mocsár és a homok ellen folyik. Erdély területén pedig két hatalmas természeti erö állandó küzdelmének lehetünk tanúi. E két erő az emberi munka s a vele szembenálló erdő. Az alábbi nyers vázlat megmutatja, hogy az évezredeken át müvelt föld miként válik 
egy-két évszázad alatt ismét rengeteggé. A régészet egyik legszebb feladata e küzdelem lefolyásának követése és értelmének megfejtése. Az egymást váltó kultúrák halmazát ennek az állandóan váltakozó küzdelemnek a dinamikája füzi egységbe, s adja meg értelmét mind egykori önmaga, mind pedig a ma élő ember számára.

$\mathrm{Az}$ ilyen módon értelmezett régészeti kutatómunka tehát beletorkollik a mába. Nem azért, mert az időrend folyamán el kell érkeznie a jelenkorig, hanem azért, mert olyan eröket kutat, amelyek ma is elevenen hatnak. A leletek településtörténeti értékelése ugyanis nem önmagával méri az egyes kultúrák teljesítményeit, azok müveltségi fokának, müvészetének, társadalmi szerkezetének, s más vonatkozásainak értékét, hanem elsősorban abból a szempontból elemzi az emlékeket, hogy az ember milyen mértékben volt képes egy adott területet munkájával a müveltségbe beilleszteni. Élősdije volt-e csupán földjének, vagy átformálta azt a maga képére. Természetes, hogy a lakott területek tágulásának vagy összezsugorodásának nemcsak népsürüségi okai voltak, hanem az egyes müveltségek természete (pl. földmüves vagy pásztor nép) is nagymértékben megszabja a földfelület kihasználásának mikéntjét és mértékét. Települést-szabó ereje van az élethez szükséges nyersanyagok jēlenlétének (pl. a só) s a viz közelségének egyaránt. Azonkívül egy-egy terület szükebb határain túl beletartozhat az eurázsiai élet lüktetésébe is, s e nagy térségek erövonalai magukra vonzzák a települöket (pl. kereskedelmi utak). E tovább is sorolható tényezökre állandóan figyelve kell kialakítanunk egy-egy kutatott terület emberföldrajzát. E formálóerők felismerése egyúttal tárgyilagos méröeszközt is ad kezünkbe a népek értékelésére. Ha például ismerjük egy nép megjelenésekor egy vizsgálandó terület állapotát $\mathrm{s}$ ismerjük e terület objektív jelentőségét, akkor lemérhetjük azt a munkát, amelyet e nép élete folyamán ebben a térségben kifejtett, aszerint, hogy képes volt-e az adottságok fokozására és újabb területeknek az emberi élet szolgálatába állítására, vagy csupán élősdije volt a területnek s alulmaradt a természeti erökkel szemben.

$\mathrm{Az}$ alábbi nyers településtörténeti vázlat elkészítésekor a következő kérdésre igyekeztem feleletet kapni: milyen volt Erdély földjének állapota a honfoglaláskor? E kérdés adattárát térképezve, mindinkább arra a meggyỏzỏdésre jutottam, hogy nem elegendö csak a honfoglalást közvetlenül megelőző népvándorláskori állapot vizsgálata. Észrevettem ugyanis, hogy a gót hóditás korától kezdve egyes területeken - még hozzá szinte törvényszerủen egyre nagyobb területeken - hiányoznak a leletek. E jelenség okát kutatva a római Dácia, söt az azt megelöző korok állapotát is meg kellett figyelnem. E megfigyelési sorból kibontakozott a kezdetben indokolatlannak tetsző lelethiány belső logikája. Még jobban meggyözött e módszer helyességéröl az, hogy az erdélyi medencének a honfoglalás utáni lassú népi kitöltése láthatólag az elözö másfélezer év elnéptelenedésének rendjét követte, de fordított menetben. Elöször tehát a népvándorlás késöi szakában még lakott területek népesednek újra be, s a lassú elönyomulás mindig a földterület egykori elhagyásának fokozataiban tölti ki menetesen újra a medencét, míg végre az őskor nagy parasztkultúrái legnagyobb kiterjedésének megfelelő területet hódít meg ismét. E térképvázlatsor készitése közben nemzetiségeink helyfoglalásának településföldrajzi logikája is 
új megvilágitásba került: abban a korban jelennek meg, amikor a magyar terjeszkedés a legrégibb idők óta lakatlan területek határáig ér. Ezek a még szabadon hagyott, vagy gyér rajokkal megszállott területek fogadták be a telepes szászságot $\mathrm{s}$ a földműves életmódot még nem ismerö, pásztorkodó román népet.

Ezek után röviden ismertetem azokat az alapelveket, amelyek munkám közben kialakultak, s amelyek mintegy a régészeti településtörténelem szükségszerü korlátai, egyelöre csak bizonyos határokon belül engedik meg a mozgást és az eredmények pontosságát. Az első kérdés az, hogy a régészeti emlékanyag mennyiben alkalmas településtörténeti megállapításokra. Helyesebben úgy tehetnők fel a kérdést, hogy egy alaposan át nem kutatott területnek inkább a véletlen semmint a céltudatos kutatás által felszínre hozott leleteiböl lehet-e településtörténeti következtetéseket levonni. Vajjon az, hogy egy-egy területröl még nem ismerünk leleteket, nem csupán a kutatás elégtelenségét bizonyítja-e? Ez a kérdésfeltevés még jobban elgondolkoztat akkor, ha megnézzük Méri Istvánnak a Borsa-völgyröl szóló kéziratos jelentését. Méri István az Erdélyi Tudományos Intézet munkaközösségében a Borsavölgy régészeti felderítését vállalta. Bejárta Kide, Borsa, Csomafája és Bádok területének jóformán minden talpalatnyi földjét. Csupán a felszíni nyomok alapján több mint húsz telepröl, temetöröl számol be. Ugyanerröl a területröl eddig csupán három öskori és egy rómaikori lelöhelyet ismertünk. Erre a négy lelöhelyre is a véletlen vezette az embert. Méri István jelentésében valószínünek tartja, hogy a felszíni nyomok alapján megállapított művelödésnyomok az ásatások megejtésével még gyarapodhatnak. Mindezek után még nagyobb valóságértéke lesz felvetett kérdésemnek, hogy vajjon a módszeres területbejárás és ásatás elött lehetséges-e egyáltalán településtörténeti következtetések levonása. Ha a Borsavölgy területét egész Erdélyen belül nézzük és térképre vetítjük az eddig ismert négy adatot, akkor ezek feltétlenül elárulják a völgy őskori és rómaikori megszállását, de semmit sem mondanak a megszállás tömörségéröl, tehát a terület népességének sürüségéröl. E megállapításból már le is vonhatjuk a régészeti leletek településtörténeti kiaknázásának egyik alapelvét: a rendszeres kutatások elvégzése elött csak egy-egy kultúra, vagy nép kiterjedésének laza határaira következtethetünk, de az eddig felszínre került leletek nem alkalmasak a pontosabb településtörténeti kép felvázolására.

Szorosan összefügg az elsőnek felvetett kérdéssel a második kérdés, amelyre felelnem kell: miképen állapitható meg a leletekböl egyes területeknek egy-egy korszakban való elnéptelenedése? A természetes válasz erre csak az lehet, hogy ha egy nagyobb - néha megyényi - területen már felszínre hozott a véletlen, vagy a rendszeres kutatás több kultúrára valló leletsorozatot, de ezek közül következetesen hiányoznak bizonyos korok jellegzetes emlékei, akkor a nagy számok törvénye alapján ezt a területet a hiányzó leletek korában elhagyottnak kell tekintenünk. Különösen akkor meggyőző ennek az elvnek az alkalmazása, ha a mai lakosság szempontjából értékes és kevésbbé értékes leletek képviselik a kultúrákat. Például ha egy területről már nagy számmal ismeretes újabb-kőkori cserépanyag, de a szántóvetőnek sokkal jobban feltünố fémholmi 
nem került elö, s nincsen a fémkorszakokra jellemzö kerámia sem, akkor nagy valószínüséggel állithatjuk, hogy a terület az újabb-kökor óta elnéptelenedett, vagy legalább is jelentős élet nem lehetett rajta. Ez a valószínüség szinte bizonyossággá változik akkor, amikor azt figyelhetjük meg, hogy egy kezdetben lakott, majd feltételezetten elnéptelenedett folt az idők során mindinkább nagyob és nagyobb lesz, az élet tehát mind szükebb területekre szorul.

E laza értelmü településtörténeti értékeléskor teljesen elhanyagolhatónak tartom a földfelület kopásának, mint a leletek felszínrekerülése okának, tényezöjét. Elvileg ugyanis úgy kellene elképzelnünk, hogy az idő és a földmüvelés által koptatott hegy- és dombodalakon gazdagabban bukkannak elö a föld mélyén rejtözö emlékek, a völgyekben pedig a föléje rakodó hordalékréteg mindinkább mélyebbre takarja öket. Azonban a völgyekben sürübb a népesség $s$ állandó földmunkája (szántás, ház- és kútépítés, stb.), továbbá a folyók és patakok medrének állandó vándorlása a mélyebb rétegekbe jutott emlékeket is felszinre hozza. Ilyenformán az oldalak természetes kopása és a völgyekben folyó emberi munka körülbelül kiegyenlíti a leletek elökerülésének számarányát. Hozzá kell vennünk még mindehhez, hogy Ẽdély területének népi kitöltése ma nagyobb, mint történelme folyamán bármikor. Nem számolhatunk tehát azzal, hogy a lelettérképek üres foltjai onnan származnak, hogy ezekre a területekre nem jutott még el az ember.

Bizonyos esetekben végleges településtörténeti megállapításokat is leolvashatunk a leletek térképezéséböl. Véglegesnek tekintjük ugyanis eredményeinket akkor, ha a leletek elöfordulásának határa valamennyi egymásfölé rétegeződő műveltségnél egybeesik s e határ egyúttal nagy földrajzi egység határa is. $\mathrm{Ez}$ a helyzet például az erdélyi medence nyugati határánál: az őskortól kezdve a magyar honfoglalásig szinte teljes pontossággal ugyanazt a határvonalat kapjuk eredményként. Nem lehet kétséges tehát, hogy ez a vonal volt az emberi élet terjedésének határvonala, mindaddig, míg a hegyipásztorkodó román nép meg nem szállotta a más településre alkalmatlan erdős, hegyi terepet.

$\mathrm{Ez}$ az utóbbi példa egyúttal figyelmeztet a régészeti leletek településtörténeti értékelésének és a növényföldrajznak állandó egymásrautaltságára. Különösen jelentös lenne e szempontból az aljnövényzet nélküli lomberdők kiterjedésének vizsgálata. Egyelöre azonban az a helyzet, hogy ebben a kérdésben épen a leletek elterjedésének van döntö szava, mert az erdőhatárok ingadozását épen a régészeti és okleveles adatok összegezésével rajzolhatjuk meg, a földrajztudományi elömunkálatok e téren még nagyon hiányosak. Nem kételkedem azonban abban, hogy egy-egy terület fokozatosan megfigyelhető elnéptelenedését épen az okozza, hogy az intenzív földmüvelés felhagyásával lazán megszállott részeket az embertől fokozatosan visszahódítja az erdő. A rendszeres erdöirtások, úgy látszik, már a korai vaskor óta szüneteltek Erdélyben s e nagy idötávlatban a másfélszázados római uralom sem jelentett említésreméltó változást.

A munka közben felismert tényekböl kristályosodott ki a kutatás mai állása mellett elérhetỏ legnagyobb bizonyosság útja-módja. Ez eleve megszabta alábbi nyers településtörténeti vázlatom elkészitésének módszerét. 
A módszer alapja a nagy számok törvényszerüsége. Az egyes nagy korszakokon belüli fínomabb rétegezödést épen ezért elhanyagolandónak gondoltam, bár tagadhatatlanul szükséges lenne e részletekre bomló munka elvégzése is. İgy tehát például nem bükki és tiszai kultúráról beszélek, s nem említem az újabb-kökor többi mủveltségi fokozatait sem, hanem summázottan az újabb-kökorban lakott területeket térképeztem. Ugyanígy kiesnek a bronzkor egyes szakaszai is az értékelésböl. A vaskortól kezdve azonban olyan folyamatot figyeltem meg, amelynek végsỏ kifejlödése a magyar honfoglalás korában következik be, igy tehát e korokat már kisebb szakaszokban kellett térképeznem. Térképvázlataimon tehát a magyar honfoglalás kora felé közeledve, mindig kisebb és kisebb időszakok népesedési állapotait rögzítettem.

Erdély őskori leleteinek felsorolását sok kiváló kutatónk munkája után legutóbb Roska Márton végezte el Repertori u mában. Summázott őskori térképeim alapjául épen e Repertorium lelöhelytérképei szolgáltak. Bár e mü időtálló gyüjtötevékenység és kutatás eredménye, tudományos rendszerezése nem mindenben fedi az újabb eredményeket, s igy ez is egyik oka volt annak, hogy kénytelen voltam elhanyagolni az egyes korok fínomabb tagolását.

A római Dácia határainak megrajzolásakor Torma Kánoly, Buday Árpád, Alföldi András, Szilágyi János és Ferenczi István munkáit használtam, a keleti limes kérdéseinek tisztázásához nagyban hozzájárult Paulovics István sajtó alatt lévő munkája. Munkám egyik fontos eredmé. nye azonban épen az volt, hogy a limes katonai határa nem fedi a terület tényleges népi kitöltését. E tekintetben további döntő bizonyságokat várunk a római emlékek repertoriumától. Torma Károly R e pertori u má nak térképezése, valamint Novák József és Pálfy Antal szives közléséböl megismert adatok kétségtelenné tették elöttem, hogy a kelta és dák korban már elnéptelenedett területeknek a gótok alatti további zsugorodása egyúttal azt is jelenti, hogy ezek a területek a római korban sem népesedtek be.

Erdély népvándorlás- és honfoglaláskori adatait, az előző irodalom átdolgozásával és a közöletlen leletek összegyüjtésével magam állítottam egybe.

$\mathrm{Az}$ adatok és a részletmegállapítások nagyrészében tehát nagyérdemü elömunkálatokra támaszkodhattam, sőt sok esetben készen találtam feldolgozásukat is. Azonban a leletek településtörténeti szerkezetének vizsgálata s logikájuk felismerése e rövid vázlatban történik meg elsőízben. E vázlatnak néhány véglegesnek sejthetö eredmény közlésén kívül elsőrangú célja épen az lenne, hogy felhívja a figyelmet e munka terebélyesítésének szükségszerüségére. Nyilvánvaló, hogy a régészeti anyag a magyar településtörténelem számára igen fontos lehetőségeket rejt magában. A honfoglalás utáni népi kitöltés fokozatainak az elözmények szerkezetének ismerete nélkül fel nem fedhető törvényszerüségei a helynévkutatáshoz, településmorfológiához, söt mint kiderült, a nemzetiségek betelepüléséhez is becses adatokat szolgáltatnak. Ehhez azonban szükséges a régészeti munka eddigi módszereinek gyökeres átalakítása. Az új munkamenet most formálódik, s kristályosodása még hosszú időt vehet igénybe, 
Az őskortól a $\mathrm{Kr}$. u. X. századig, tehát a magyar honfoglalás koráig ismert régészeti adatokat három térképben összegeztem. Ezek közül az első a bronzkor végéig, a második a Dáciai limesig, a harmadik pedig a népvándorlást befejező magyar honfoglalásig süríti az egyes müveltségi korokat. A negyedik térképen a vaskor kezdetétöl megfigyelhetö elnéptelenedés menetének egybefoglalását kíséreltem meg. $\mathrm{Ez}$ utóbbin feltüntettem a XII. századi állapotot is; ebböl leolvasható, hogy a magyarság két és fél évszázad alatt szinte mai határáig tölti ki ismét az erdélyi medencét.

I. térkép. 1. A z ő s kő k o r. E korszaknak eddig ismert lelöhelyei már bizonyos törvényszerüséget árulnak el. A Körös völgye, a Nagyszamos felső folyása, tehát a Radnai-hágó felé vezető út, a Bodzai- és Törcsváriszoros megszállása, meg a Vöröstoronyi-, valamint a Vulkán-szoros elöterének benépesítése első pillanatra szembetünik. Valamennyi eddig felsorolt lelöhely az erdélyi medence peremvidékeinek bejáratánál van. A többi lelőhelyek is a medence szegélyén helyezkednek el: a Kisszamos felső folyása, a Maros középső szakasza, továbbá a Hargita és a Baróti hegység nyugati lejtöjéröl ismeretesek eddig leletek. Az őskőkor embere tehát kisebb, egymástól elszigetelt csoportokban üli meg földünket. Meg. jelenése nem változtatja meg a táj jellegét, mert életéhez csak a föld magaadta javait használja fel. Az Erdélybe torkolló utak körüli elhelyezkedést nagyobb távlatokban az őskőkor eurázsiai népmozgalmai értetik meg. E kor egyes szakaszainak népei s állatvilága ugyanis szinte egymást felváltva, hol Afrika, hol pedig Ázsia felöl áramlik a kiegyensúlyozottabb éghajlatú Európa felé. A szorosok környékének benépesedése tehát a természetszabta utak mentén vándorló népek megtelepedését jelzi. Ezek a helyek lesznek később csomópontjai a kereskedelmi hálózatnak s ezeken keresztül áramlik kelet-nyugat s észak-déli irányba a vándorló nép évezredeken keresztül.

Az öskőkor végén beálló eljegesedés s az utána bekövetkezett olvadás nagyjából mai jellegére formálja át Európa növénytakaróját. A megritkult lakosság elöl a nyirkos, egyre melegedö éghajlatban a lombos erdö hódítja meg a területeket. Ebböl az átmeneti korból csak az Erdélyi Érchegység északnyugati öbléböl ismerjük az ember nyomát.

2. A z ú jabb kökor. E korszak embere már nemcsak élösdije a földnek, hanem hozzáfog a föld megmüveléséhez is. A korszak végén a lakosság már majdnem az egész medencét kitölti sürü telepes-rajaival. A népi kitöltés folyamatát a leletek világánál még csak botladozva követhetjük, de a munka menetének szakaszairól a párhuzamok alapján elég szemléletes képet rajzolhatunk. Kezdetben nyilván csak a folyók völgyeinek termékeny lapályait fogják müvelés alá, de már aránylag korán meg. jelenik az újabb kőkor embere a kis patakok szinte hozzáférhetetlen völgyeiben s eldugott erdőségeiben is. E nagyméretü terjeszkedésnek kettős oka lehetett. Kézenfekvő feltennünk, hogy e kirajzás egyik oka a természetes népszaporodás volt. Kezdetleges földmủvelés, valamint a komoly szállítóeszközök hiányában ugyancsak kezdetlegesnek minösíthetö ipar és kereskedelem mellett, a gazdaságtörténészek számítása szerint $1.7-5$ 


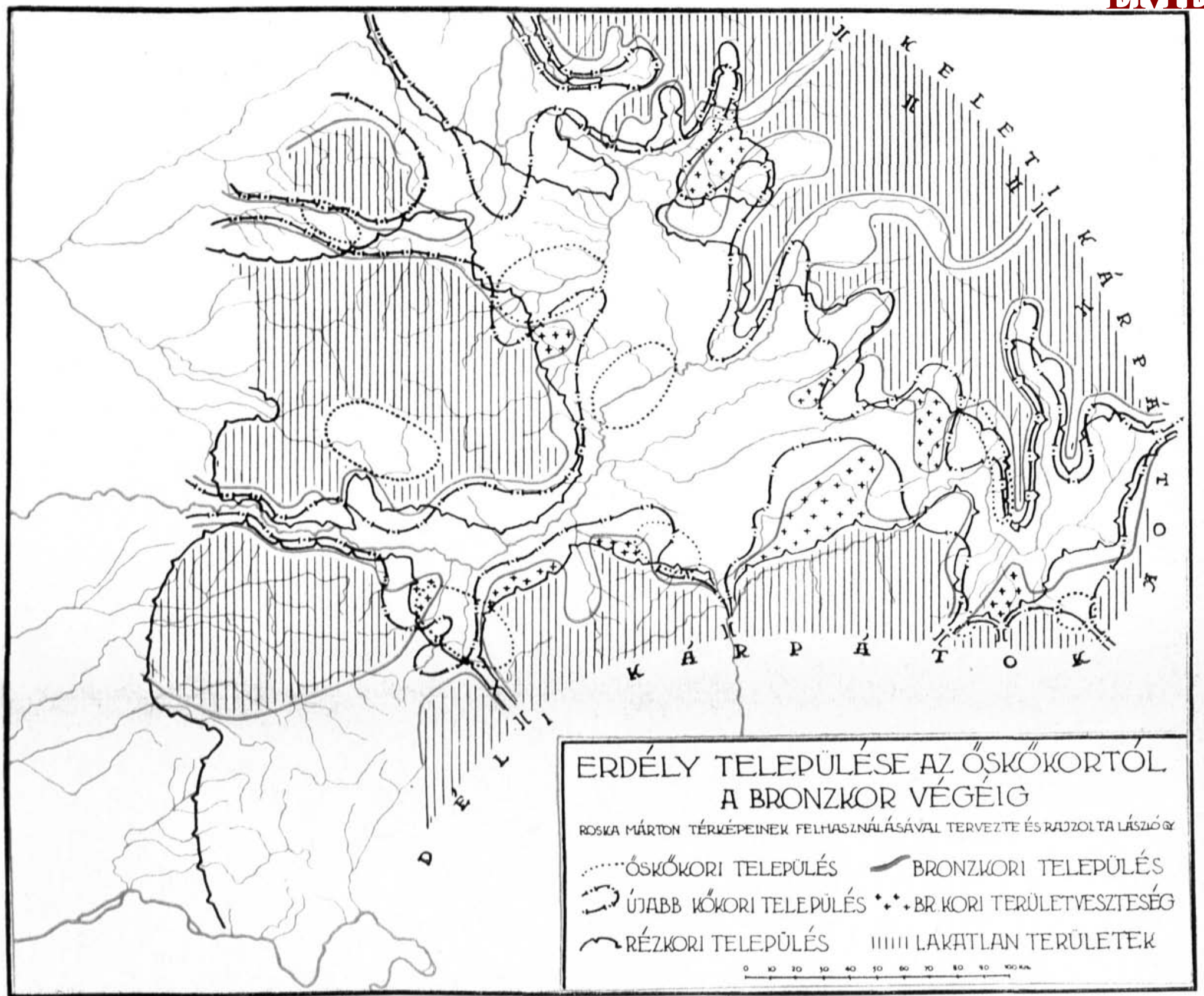




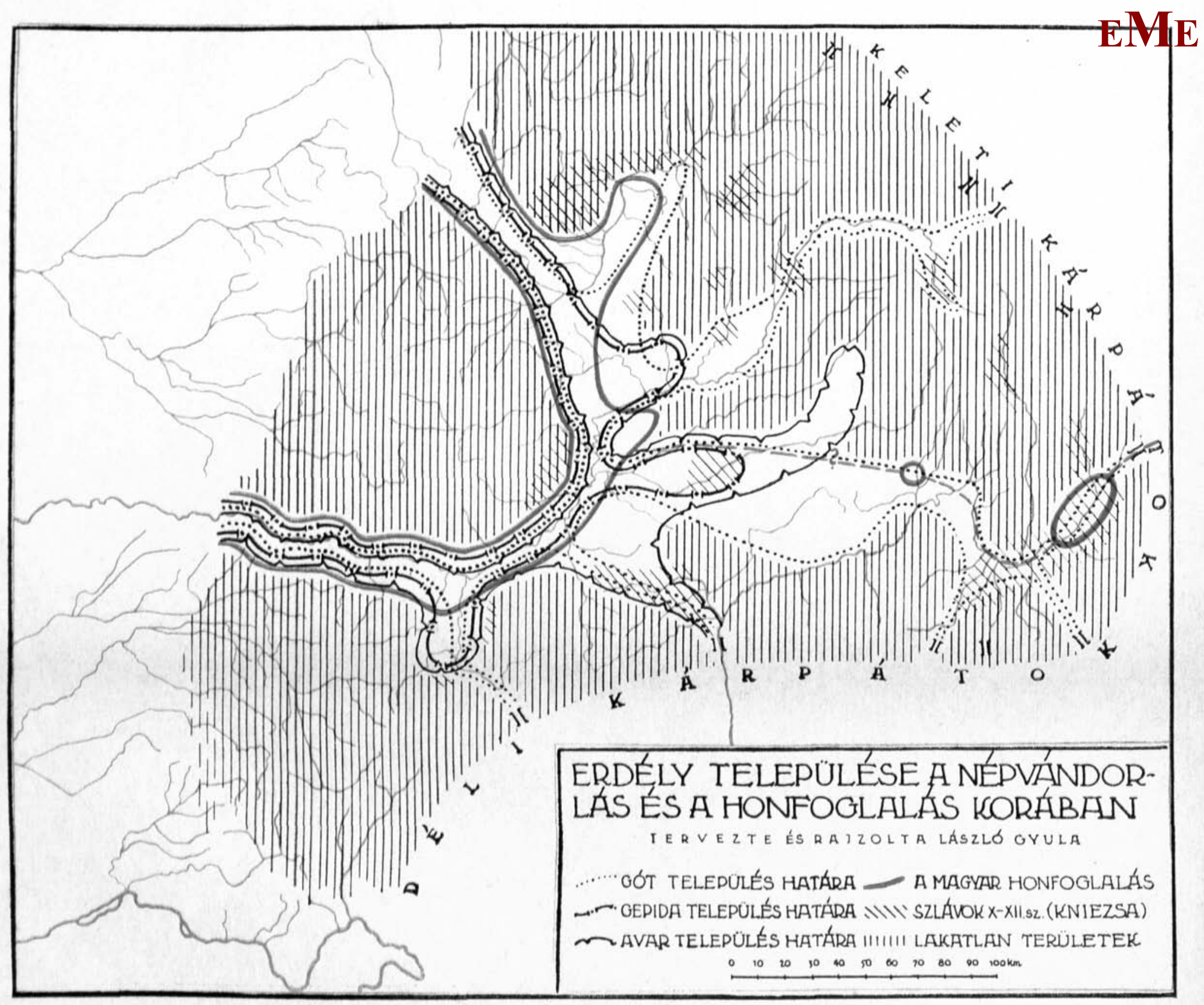




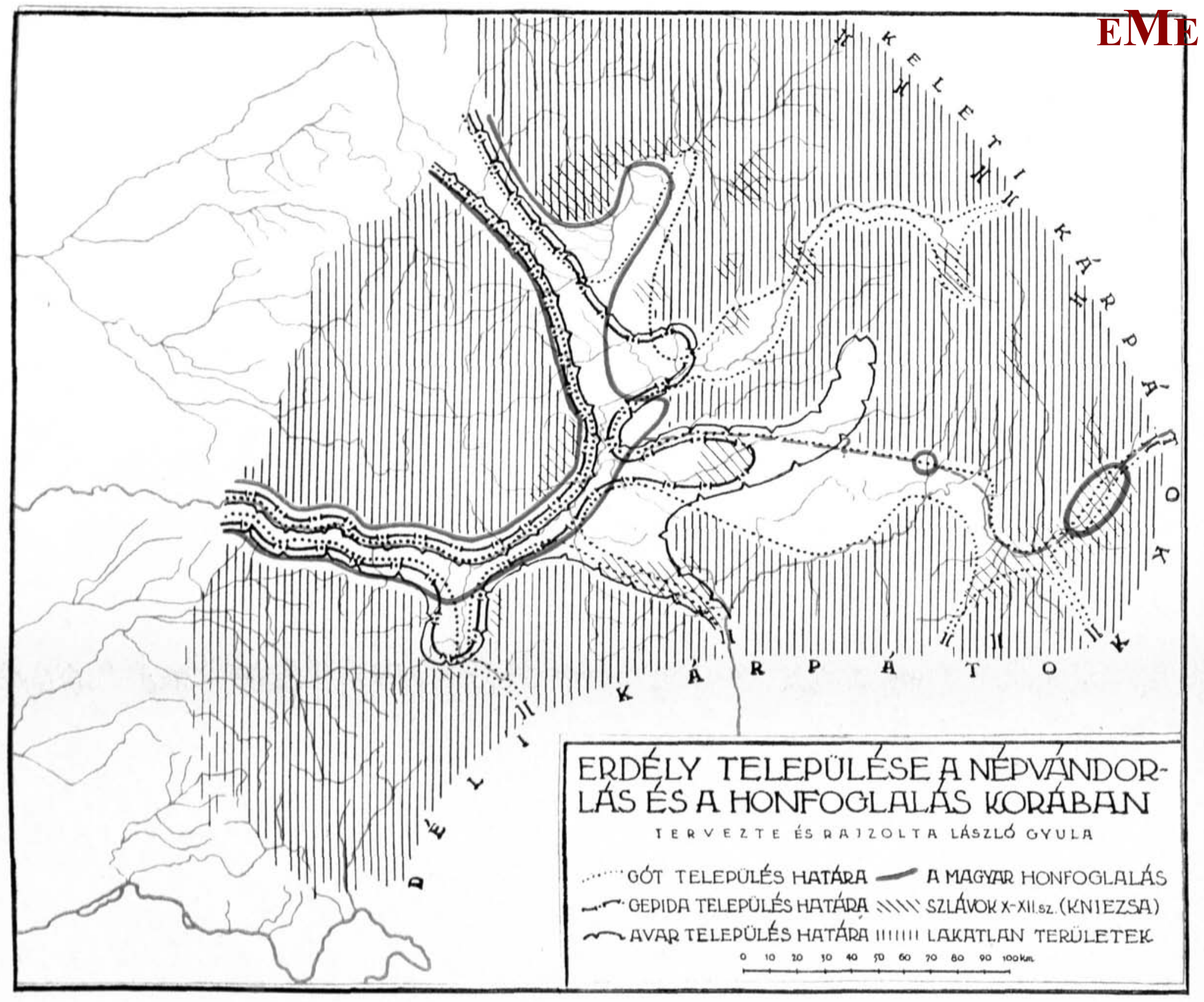




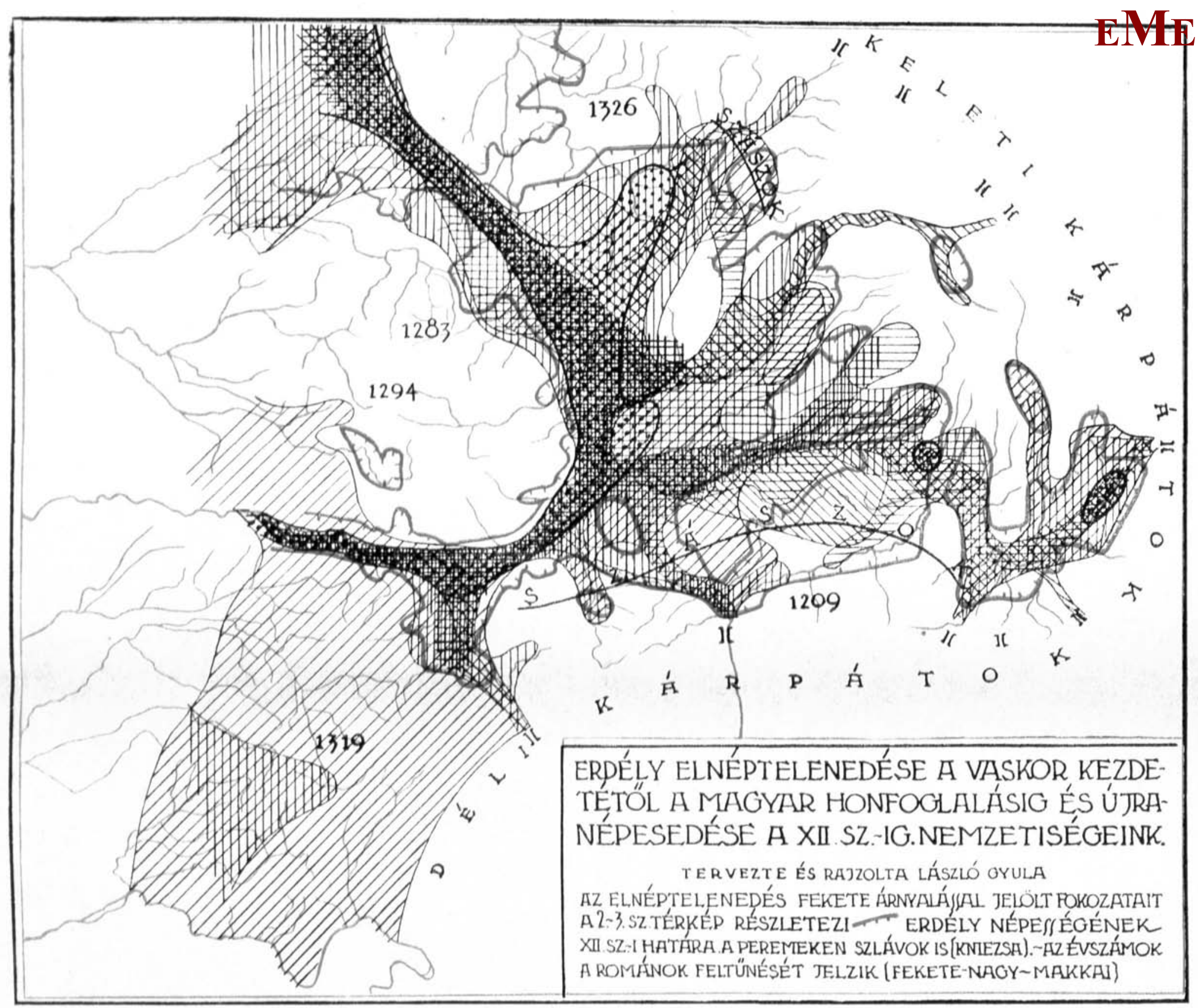


négyzetkilométerenkénti átlagos népsürüségénél a föld nem tud többet eltartani. Igy tehát a nemzedékenkénti rendes népszaporodás is újabb és újabb területek meghódítására kényszeríti az embert. A még sok ízben ma is lakatlan területeken talált leletekböl arra is következtethetünk, hogy e kirajzás útmutatói nem csupán a patakok voltak. Erdély őserdeiben dúsan tenyésztek a különbözö vadgyümölcsök. E gyümölcsösök vonzották az öskor emberét s ezek felfedezése lehetett a kirajzás második oka, illetöleg a népfölösleg elhelyezkedésének irányítója. A párhuzamok világánál egy-egy ilyen település menetét is felvázolhatjuk. Az irtványfalvak telepesei elöször a gyümölcsfák közül irtották ki a lombos fákat. Az irtás ebben az esetben csakis szerszámokkal mehetett végbe. A telep lassú népi telítödése újabb terjeszkedést követelt meg, s a környezetet lassan alkalmassá kellett tenniök a földmüvelés és állattartás számára. A telep peremterületeinek írtásakor nyilván égetéses módszerrel jártak el, s a kapott hamus területekben egyúttal kitűnő termőtalajt nyertek. Az erdő újrasarjadzásának meggátlásáról nyilván a friss zöld hajtásokhoz hajtott háziállatok gondoskodtak. A kapás földmüveléssel és az állattenyésztéssel új elem vonul be Erdély földjére. Megkezdỏdik az ember és az erdő máig tartó állandó küzdelme. A mindinkább terjeszkedő irtványtelepülések körei lassan összeérnek s az erdő mind szükebb és szükebb területre szorul. De egy-egy földdarab idöleges elhagyása is elég ahhoz, hogy a munkát elölröl kelljen kezdeni, mert a dúsan tenyésző erdő rövid idő alatt visszahódítja a területet.

Az újabb-kőkorban kezdődik tehát meg a nyers táj emberi megformálása. Az ember terjeszkedésével a természeti erök ellenében a maga eröit juttatja érvényre, s így a lakott tájon többé nem a természet kúsza erőkötegei uralkodnak, hanem a megtelepedett emberé. Falvak keletkeznek, erődítmények s megművelt földek váltják egymást, a nyers tájból megmüvelt táj keletkezik.

$\mathrm{Az}$ újabb-kőkorban lakott terület határait igyekszem részletesen felvázolni, hogy a rákövetkezö korok ismertetésekor ne kelljen az összes helyjelöléseket ismételnem, hanem csak a gyarapodás és csökkenés mértékét viszonyíthassam az újabb-kőkor részletesen megrajzolt határaihoz.

Északnyugatról két kapu torkollik Erdélybe: a Királyhágó és a Körös mente, valamint a Meszesi kapu. A Lápos mentén felfelé igyekvő telepesek legfennebb laza kapcsolatban lehettek az erdélyi medence lakóival. A meszesi kapun átjöve, a Szamos-könyököt széles ívben kerüli meg az északi határvonal, Búzamezỏ tájékán lépi át a Szamost, s nagyjából a Nagyszamos sávját követve, a Szalva mentén az Ilosvai hegység és a Radnai havasok közé ékelödik, innen a Szamos balpartján a Szépleshez (Cibles), majd a Sajó középső folyása mentére ível. Itt déli irányba fordul és a Komlód mentén majdnem a Marosig nyúlik, majd felkanyarodik ennek középső folyásáig, a Kelemen havasok aljáig. Átcsap a Görgényiés Mezöhavas lábainál a Nagyküküllö középső részéig, s itt megtörik. A Nagyküküllö mentét követi egy darabon a határ, innen a Homoród partjára vezet $\mathrm{s}$ ennek mentén az Olt-könyök felé tart. A Baróti hegységet megkerülve, követi a folyót Felcsík és Alcsík területére, majd a Bodoki hegység lábainál egyenesen az Ojtozi szorosnak vezet. 
Az újabb-kőkori ember megszállotta a Háromszéki medencét és a Barcaságot is, s élénk forgalom lehetett e korban a Bodzai- és Tömösiszorosok kapuin, nemkülönben a Törcsvári-szorosban. Innen a határ a nagy Olt-kanyart átvágva, szinte a Nagyküküllöig ível, úgy hogy csak a küküllőmenti kapu köti össze keskeny sávjával a Mezőség és a Háromszéki medence népét. E kaputól a Vöröstoronyi-szoros felé vezet a határ, majd a Székás felé kanyarodva, egy darabig a Maros mentét követi, s a Sztrigy és Cserna lapályát magába ölelve, a Maros mentén torkollik az Alföldre.

A nyugati határvonal nagyjából a Meszesi kapu és a Maros-könyök ívében indul, de mielött eléri a Marost, közvetlenül Kolozsvár alatt mélyen a Mezöség felé nyúlik. E vonal tehát a Király-erdő, a Bihar-egység és a Gyalui havasok lábánál vezet. A leletek határa a Maros-könyöktöl az Ompoly mentén az Erdélyi Érchegység déli oldalát magába foglalva, kisebb-nagyobb kitüremlésekkel nagyjából a Maros jobbpartjának mentét követi.

E határvonalat felvázolva meg kell jegyeznem, hogy sem az újabbkőkor, sem pedig a soron következö műveltségek tárgyalásakor nem térek ki a kultúrák terjeszkedésének irányára, természetére és tagozódására, valamint a szomszédos területekkel való összefüggésére. Tehát az egyes korszakokat nem fejlödésük menetében, hanem legnagyobb kiterjedésük állapotában vizsgálom. E szükítés szükségességéröl s kényszerü hátrányairól az összefoglaló részben még beszélek.

3. A réz k or. A réz felfedezése és bányászatának megindulása, valamint a fémeszközök nagyobb lehetöségei újabb térhódítást tettek lehetővé. Általában úgy látszik, hogy a fém megjelenésével egyidőben azt a területet, amelyet már az újabb-kökor paraszti kultúrája meghódított, erösebb iparosodás és messze területekre nyúló kereskedelmi utak gazdagítják. Ez egyúttal hatalmas mértékben megnövelte a föld eltartóképességét, s így ugyanazon a területen nagyobb lélekszámú lakosság találhatott megélhetést. Nyilván ez a magyarázata, hogy bár a rézkorban területi terjeszkedést is megfigyelhetünk, ez a terjeszkedés nem olyan mértékü, mint amilyent az új anyag hozta technikai forradalomtól elvárhatnánk. A rézkorban a föld megmunkálásának kizárólagos eszköze még mindig a kapa. s bizonyos mértékig ez is határt szabott a földterület kiaknázásának.

$\mathrm{Az}$ újabb-kőkor határait nyomról-nyomra kísértem, az alábbiakban ennek tudásában csak a gyarapodás és a veszteség mértékét vizsgálom.

A láposmenti település kisebb térre szorul. A Meszesi kapunál széles sávban Erdélybe torkolló határ Szolnok-Doboka megye délnyugati területét, ahol az újabb-kőkor embere virágzó telepeket létesített, kikẹrüli. A Nagyszamos mentét nagyjából az elöző kor népi határáig lakják s’ északi mellékvizei közül a Széples (Cibles) partján is megjelenik az ember, a Szalva mentén pedig még tovább hatol elöre. A Sajó vízrendszere lakott, de déli peremén a mezőségi tavak tájékán területveszteséget figyelhetünk meg. A Maros mentén, úgy látszik, nem jut fel a Görgény patakáig a határ, ezzel szemben a Mezöhavas és a Hargita nyugati lejtöin a Nyárád és a Kisküküllő forrásvidékéig hatol fel az ember. A két Küküllö közt is keletebbre tolódik a határ. A Nagyküküllő és a Homoród felső szakaszán 
némi területveszteség mutatkozik ugyan, de az Olt-kanyar és a Homoród között tekintélyes új területek szolgálják az embert. A Baróti hegység déli csücskétöl az Ojtozi-szorosig kisebb eltérésekkel az elöző korszak határain járunk. A Bodza-szoros használatára nincsen adatunk, de a Tömösi- és Törcsvári-szoros e korban is jelentös szerepet töltött be. Innen az Oltkanyar felé vonul a határ, majd az Olt jobbpartján a Vöröstoronyiszoroshoz, onnan pedig újabb területeket foglalva magába, a Vulkánhágóhoz vezet. A Kárpátoktól kisebb-nagyobb eltérésekkel nagyjából az újabb-kőkori határ mentén követjük a rézkori település vonulását a Maros mentére.

Az északi határ elhagyja a Körös völgyét és a Meszesi kapun keresztül vezet be Erdélybe, $\mathrm{s}$ innen széles ívben (a Kisszamosnál területveszteséggel, az Aranyos táján jelentős újabb területekkel) a Maros-könyökig ível. Nagyjából Gyulafehérvár tájáig a Marost követi, tehát a régebben már lakott területsáv egyrésze elnéptelenedik. Innen az Erdélyi Érchegység terraszain vonul nyugat felé, s a Solymosi hegység közében majdnem a Fehér Körös forrásvidékéig nyúlik fel a hegyekbe. A további leletek a hegység déli pereme mentén kísérik az Alföld felé a Marost.

Bár az újabb-kökor és a rézkor lakott területe nagy tömbjében azonos, az erdélyi medence meghódítását a rézkor embere tovább bővíti.

4. A b r onzkor. A keményebb és ellenállóbb bronz felfedezése fokozott üteművé teszi azt a fejlődést, amelyet az elözö koroknál vázoltam. A kapás földmüvelést felváltja lassan az ekés művelés, és a korszak végéről való sarlóleletek nagy száma is a gabonatermelés erős fokozódását jelzi. A kereskedelmi kapcsolatok Észak-Olaszország és a Balkán felé megerősödnek, sőt az erdélyi bronzáru útja Dél-Oroszországon keresztül a távoli Kaukázusig is követhető. Óriási földdarabokat hódít meg új eszközeivel az ember, s szinte Erdély minden megmüvelhetö területét munkába fogja. E hatalmas fejlödés ellenére is megfigyelhetök már e korban is területek, amelyekröl visszahúzódik az ember.

A Körösvölgy a Királyhágóval egyetemben újra életre kap. Az eddig lakatlan Szamos-könyök egészen a Lápos mentéig müvelés alá kerül, s biztos nyomai vannak a Radnai-hágó használatának is. A Sajó meg a Beszterce forrásvidéke benépesedik, s a két Küküllö közt is keletebbre tolódik a határ. Az Ojtozi- és a Törcsvári-szoroson folyó élet mellett a Tömösi- és a Bodzai-szoros jelentősége elhalványodik. A Vöröstoronyiszoros és a Vulkán-hágó közt a Sebespatak mente is belekerül a megszállott részekbe. A lakott terület határa a Vaskapu-hágón keresztül elöször torkollik bele Hunyad és Krassó-Szörény déli hegyrendszerébe. E hatalmas területnyereség mellett a következö helyeken figyelhetünk meg területveszteséget: A Szalva felső szakasza mentén, a Sajó torkolata körül, a Kisküküllö mentén, a Nagyküküllö és a Homoród közén, a Tömösiszoros felett, a Hortobágy és az Olt közében. A Székáspatak alatt és a Sebes és Sztrigy völgyében is fennebb nyomult a Kudzsiri havasok erdeje.

II. térkép. Míg az eddig tárgyalt kultúráknál a nagyobb folyók mellékvizeinek környéke is benépesült, bár a benépeseđđés eröhálózatának iránya nem mindig a vizek mente volt (pl. Szolnok-Doboka megye településének vezetője nem a Kisszamos mente, hanem a Mezőségi tavak és 
Várkudu-Bethlen közt húzható tengely), a vaskorban a lakott terület szinte csak a nagy folyók mentére zsugorodik. A területveszteség a bronzkori kiterjedéshez képest igen nagy. Az elnéptelenedés egyik föoka talán az a nagyirányú népmozgás, amelyet a bronzkor végén figyelhetünk meg, s amelynek hátterében a dél felé irányuló illyr-dór vándorlás áll. Hozzájárul mindehhez a kimméri és szkíta hódítás is. A térképre tekintve, szinte az a benyomásunk, mintha a területet a korábbi lakosság zöme elhagyta volna, s új lakosság kezdené újra benépesiteni Erdélyt. E népmozgalom kiteljesedését megzavarják ‘a keleti lovasnépek hódításai. 'Az e korban lejátszódó katasztrófákat élénken példázza a földberejtett kincsleletek sora. E kezdeti zavarok a most következö ezer év folyamát végig meghatározzák, s csak a kelta-dák kor fellendülése hoz némi javulást az egyetemes romlásba.

1. A k orai-vaskor (Hallstatt-Villanova kultúra). A fent vázolt népmozgalmak kora még nem köszöntött be teljes egészében, s e kor sarlóleletei a földmüvelés folytatása mellett szólnak, a kereskedelmi kapcsolatok javarésze is megmaradt még. Minél inkább eltávolódunk a bronzkortól, s minél inkább helyet kap a vas használata, annál inkább zsugorodik össze a lakott terület. A határvonalat nagyjából a következöképen húzhatjuk meg: A Zilah-patak mentén keskeny lakott sáv vezet át a Meszes kapun. A lakott terület határa északon ismét kikerüli a Szamos könyökét, s csupán Dés alatt valamivel lépi át a folyót. Egyideig a Nagyszamos mentét követi, majd a Lápos-patak könyökéig csap fel, a Radnaihágót még a bronzkor örökségeként használják e korban is. Innen szinte egyenes vonalban húzódik a határ a Komlódpatak torkolatáig, majd a Maros felső fordulójáig követhetjük a lelėteket; innen visszakanyarodva, a Nyárád mentén halad a lelöhelyek határvonala, átíveli a Kis- és Nagyküküllő felső szakaszát, s a Baróti hegységhez tapadva követi az Oltot Alcsíkig. Az Olt mentéröl Kászonszéket magába zárva torkollik be a határvonal az Ojtozi-szorosba. Az Ojtozi-szorostól a Törcsvári-szorosig húzható egyenes mentét követve, ez utóbbi szorostól az Olt könyökig kígyózva keskeny folyosóként követi a Nagyküküllö mentét. A Vöröstoronyi-szoros táján az Oltot egy darabon ismét magába foglalja. A koraivaskor emberének rajai a Sebes, Sztrigy és Cserna völgyét csupán vékony rétegben szállották meg. A Vulkán-hágó e korban is közlekedési útként szolgált. A továbbiakban csak a Maros mentén találjuk meg e kor jellemző leleteit. A nyugati határ a Berettyótól indul, s nagyjából a Réz hegység, a Bihar hegység, a Gyalui havasok, az Erdélyi Érchegység és a Solymos hegység lábainál torkollik az Alföld síkjába.

A bronzkorhoz képest tehát óriási a visszaesés. A Szamos alsó folyása a Lápos mente, a Körös és Királyhágó vidéke elnéptelenedik, a Sajó és Beszterce völgye kimarad, az utóbbi terület feladása már részben a bronzkorban megkezdődik. Ugyancsak bronzkori elnéptelenedés volt az alapja az Olt- és Küküllö-köze feladásának. Elveszett e korban a bronzkorban ámenetileg meghóditott délerdélyi hegyvidék (Krassó-Szörény és Hunyad hegyei),- bár a Berzava és a Karas folyó mentén egyideig még volt élet.

Itt kell kitérnem még Erdély öskori erödítményeire. Elhelyezkedésük- 
ben bizonyos rendszer figyelhetö meg. Nagy tömegben ugyanis Csíkban az Olt jobbpartján, a Hargita tövében, majd nagyjából a Bodza-szorostól a Hargita és a Görgényi havasok nyugati oldalán halad ez az erödítménysor széles sávban, a Maros kapuját nyitva hagyja, s a másik oldalon a Kelemen havasok délkeleti peremét követi. Északon a Nagyszamos felett ivel át a Meszesi kapuig, végül a Gyalui havasok és az Erdélyi Érchegység keleti peremén találjuk sürün e védmüveket (az utóbbi jelölése hiányzik a II. térképröl). Az erödítmények zöme tehát közrefogja az erdélyi medencét. E fö vonulatokon kívül a belső terület védettebb helyein mindenütt megtalálhatók. Feltünö jelenség, hogy Erdély déli részén a vaskorban már elnéptelenedő Olt mentén úgyszólván teljesen hiányzanak. Ứgy látszik, hogy a háromszéki és csíki várak javarészét a dákok építették, a többi területeken az erödítéseknek jóval korábbiaknak kell lenniök. Hitelesítö ásatás alig néhánynál történt, de térképvázlataim alapján úgy látom, hogy zömük a vaskor elött kellett épüljön, hiszen ettől a kortól fogva az erödítmények nagy vonalai a lakott területek peremén kivül esnek. Azt is kétségtelennek tartom, hogy az erödítmények elsösorban nem kifelé fordultak, hanem az erdélyi medencéböl az ellenséges nyomás elöl időröl-időre a hegyvidék peremére felhúzódott lakosságnak szolgáltak a medence felé irányulva védelmül.

Feltünö jelenség, hogy a dáciai római limes szinte ráépül erre az erödítmény-sorra. Eszszerü lenne ezt a jelenséget úgy magyarázni, hogy az erdélyi medencéböl kiszoritott kelta és dák maradványok is ezekbe az erődítményekbe húzódtak a medence belsejéböl jövő támadás elöl, s ez tette szükségessé azt, hogy a római stratégiai határt, még a sok helyen közbeeső nagyobb lakatlan területek bekebelezésével is, úgy építsék ki, hogy ezt az erőditmény-sort is semlegesitse. Bármennyire észszerü is ez a feltevés, csak feltevés marad mindaddig, míg az ásatások nem tisztázzák e kérdéseket. Meggyőződésem azonban, hogy a kérdés felvetése már egymagában is új elemet jelent a limes dacicus értelmezésének kutatásában.

2. A s z kíták jóformán csak a Mezöséget s annak kijáratait szállják meg. A Meszesi kapu, az Ojtozi-szoros és a Vöröstoronyi-szoros mellett a Maros mentének kijáratát használták. Északon Kolozsvár felett Szolnok-Doboka és Beszterce megszállatlan maradt, csupán a Maros mentéről tört elö egy kisebb csoport Szolnok-Doboka délkeleti sarkába Noszolyig. A Maros középső szakasza és a két Küküllő köze sok szkíta lelettel szolgált eddig, innen keskeny folyósó vezetett a Feketeügy mentén Ojtoz felé. Az Olt könyökétől Fogaras irányában egy darabig az előző korban lakatlan területen is elörehatolnak, innen kezdve azonban a Nagyküküllöig terjedő rész lakatlan maradt, csupán a Vöröstoronyi szoros felé mutatnak nyomok. Továbbhaladva a Marosmente és a vaskori megszállás nyugati határvonala zárja be a szkíta település területét.

A korai-vaskor lakottságához képest tehát igen nagy a területveszteség. A már említett északi részeken kívül kiesik a Nyárád és a Kisküküllö területének jelentős darabja, a csíki medence teljesen, a háromszéki síkságon csak keskeny út vezet, s a beletorkolló szorosok közül csak az Ojtozin volt forgalom. Az Olt mentén tapasztalható csekély területnyereséggel szem- 
ben a déli részeken is további elnéptelenedést figyelhetünk meg: kikapcsolódik a Sebes völgye és a Sztrigy-Cserna területe.

E területveszteség magyarázatakéni önként kínálkoznék a szkíták lovasnomád életformája. Ez érthetővé tenné, hogy miért csak a mezőségi részeket szállották meg. A kérdés azonban nem ilyen egyszerü. Az elnéptelenedés egyik oka — az életformától függetlenül - kétségkívül az, hogy a kimmériek (?) és szkíták korában állandó háborúskodás zavarta a nyugodt fejlődést. Ez szervesen belekapcsolódva a már a bronzkor végén meginduló népmozgalmakba, mindinkább lehetetlenné tette a békés földmüvelö munkát. Az élet bizonytalansága nagyobbméretü kivándorlást eredményezhetett. Nem mernék ebben az elnéptelenedésben a szkíta lovasnomád életformának nagyobb jelentőséget tulajdonítani. Az erdélyi szkíták ugyanis kétségkívül a Dnyeper mentéröl jöve hóditották meg Erdélyt. A Dnyepermenti szkítákról pedig Herodotos világosan megírta, hogy a Kubán-vidékiekkel ellentétben ezek földmüvelök. Az elökelö réteg sírjai a Dnyeper mentén is lovasnomád társadalmi szerkezetröl tanúskodnak, s ezt a jellemvonást Erdélyben is megtaláljuk. Azonban ez csak a vékony uralkodó rétegre jellemző $\mathrm{s}$ nem a földmưves tömegekre. Mindezek alapján komoly alapot látok legalább is annak feltevésére, hogy a szkíta hódítás nem volt földmüves ellenes természetü. Valószínü, hogy a szolnokdobokai részek nem néptelenedtek el ebben a korban, mert a szkíták politikai bukása után ezen a területen újból élet van. Pedig a szkíták alatt elnéptelenedö többi területröl a későbbi korokból is hiányoznak a leletek, sőt e területek még jobban elnéptelenednek.

3. A k eltá k és dá k ok. A kelta és dák szimbiozis idején a szkíták által meg nem szállott területek egyrésze, mint már említettem, újra benépesül (vagy nem is néptelenedett el a közbenesö korban?). E területek pontosabban: Szolnok-Doboka déli része és a Beszterce völgyének egyrésze, továbbá a csíki medence (az utóbbi helyröl közöletlen leletek azt sejtetik, hogy a szkíták ezt a területet is megszállották), nagyobbszámú népességgel kell számolnunk a Háromszéki medencében. Az Ojtozi-szoroson kívül a Törcsvári-szoroson is megindul a forgalom. Az Olt északi partja a Küküllöig lakatlan ugyan, de a Hortobágy torkolatától kezdve a hallstatti időktől lakatlan területek kapcsolódnak be az életbe. A Sebes völgye ismét lakott s Hunyad meg Krassó-Szörény területén Temes megye határáig pompás dák várak sora őrzi az újonnan művelésbe fogott területet. Az erdélyi medence lakott részeinek nyugati határa ismét a régi vonalon fut, kikerülve a Királyhágót, a Bihari hegységet, az Erdélyi Érchegységet, s mint az előző korokban is, a Maros vonalba kapcsolódik bele.

A vaskortól kezdve megfigyelhetö s a szkiták alatt még nagyobb térségekre jellemző lelethiány újabb területekre terjed ki. Ủjabb területveszteség figyelhető meg a két Szamos elágazásánál; nagy kanyarral bövül a Maros és Komlód közének elnéptelenedése is. A fogarasi síkság feletti néptelen rész a Nagy-Küküllöig ível. Egyebekben a Vulkán-szorosig a vaskori település vonulatát követi a határ.

4. A ró ma i li mes ezek szerint tisztán stratégiai jellegü erődítmény volt, $s$ jóval nagyobb területet ölelt magában, mint amekkorát ebben a korban a népesség kitöltött. Palánkától Lippáig esetleg Zsidovinnál Vecel 
felé ágazva szinte pontosan azt a területet határolja, amely területröl dák leletanyagot ismerünk. A leletek és a történelmi források ebben az esetben tehát egybevágnak. Veceltől Verespatakon keresztül vezet a limes, először kapcsolva be a müvelődésbe, az eddigi aranymosás helyett az aranybányák területét. Innen nagyjából a Gyalui havasok lábánál vonul s Moigrádnál (Porolissum) erődítménnyel zárja le a Meszes kaput. Északi határa Besztercéig s keleti vonulata Barót, Oltszem, Bereck vonalig az őskori erődítménysort és a hegyek vonulatát követi. Déli, inkább eszmei határa nyilván a Kárpátokra támaszkodott, majd a Vöröstoronyi-szoroson keresztül az Olt mentén vezetett lefelé.

Abból a tényből, hogy a római hóditáskor lakatlanul talált területek. röl nincsen jelentősebb számú római népességre valló leletanyagunk, továbbá abból, hogy e területek a rómaiakat követő gót korban is nagyrészt lakatlanok, arra következtetek, hogy e területek népi kitöltése a római uralom másfél százada alatt sem következett be. İgy tehát a római gyarmatosító tevékenység sem léphette jelentősen túl a már a hódításkor meg. müvelten talált területek határát. A készülö rómaikori repertorium térképezése elsőrangú bizonyító anyaggal bövíti majd e területröl való tudá. sunkat. Megjelenéséig a fentieken túlmenöleg nem akarom tárgyalni e kor népesedéstörténetét.

Paulovics Istvánnak most sajtó alatt levö dolgozatából kiderül, hogy Dacia katonai szervezete a folyóvölgyek mentén sugárszerüen s a limesek felé egyre kisebb erejü katonasággal épült ki. Párhuzamos ezzel az a megállapításom, amelyet a vaskor településének jellemzésekor tettem, hogy t. i. a bronzkor után az élet a folyóvölgyekre szükül össze. Ilyenképen a római katonai szervezet itt is a már készen kapott adottságokba épült bele, ugyanúgy mint a limes kiépítésekor. A folyóvölgyek területeit vette erösen kézbe, s ezáltal magának biztosílotla az életfontosságú hálózatot. A délnyugati dák várak lerombolását az írott forrásokon kívül ásatások is bizonyítják.

A térképen a pirossal jelölt limesvonalon belül feltüntettem az azelött sohasem lakott, vagy a bronzkor óta lakatlan területeket, továbbá a római hódításkor néptelenül talált részeket. Ezeknek a területeknek további kiterjedését figyelhetjük meg a népvándorlás korában.

III. térkép. 1. A gót s zállásterület a Meszesi kapun vezet ki Erdélyből, Kolozsvár tájékáról keskeny sávban Alsóilosváig nyúlik fel, innen a Marosig húzódik vissza, a Komlód vizétöl nyugatra kiöblösödik, majd a Ludas patakának torkolata körül símul ismét a Maroshoz s kivezet a Tölgyesi-szoros felé. A Maros eredete táján erösebb gót teleppel számolhatunk. A Maros mente sürü gót megszállása kihagyja a Nyárád és a Kisküküllö területét és a Küküllők torkolatától a Nagyküküllö mentét követve, szinte egyenes vonalban vezet az Olt-kanyarig. A Háromszéki medence és a Barcaság mindhárom szorosát használják. Az Olt mente, a nagy kanyart nem számílva, lakatlanul maradt, de az ettől északra fekvö terüle. teken sürün találjuk a gótok emlékeit. A Küküllö torkolatától egy darabig ismét a Maros mentére szorul a népesség, s ennek völgye köti össze az alföldi területekkel az erdélyi gótokat. Közben keskeny sávban utak vezetnek a Vöröstoronyi-szoroshoz és a Vulkán-hágóhoz. A megszállott tèrület 
nyugati határa a Meszes kaputól Kolozsvár felett a Maros-könyökig ível, innen a Marost követi. Ez az erdélyi medence nyugati határa a népvándorlás egész tartama alatt, s a magyar honfoglalás is e természetszabta határoktól keletre tör.

Az előző korokban megfigyelhető elnéptelenedés tehát óriási mértéket ölt. Az elöző népességböl legfennebb némi kelta iparosréteg nyomai mutathatók ki a gót temetök edényeiben. Az átütésekkel közelebbröl Fettich Nándor foglalkozik, s ezért ezen a helyen nem bocsátkozom tárgyalásukba.

2. A gótokat követö gepi d a megszálláskor elvész a Szolnok-Doboka felé kitüremlő terület, s a Maros mentét is csak a folyó középső szakaszáig szállják meg. A két Küküllö közén sem haladnak túlságosan elöre, ettöl kezdve pedig, a Sztrigy völgyének megszállását nem tekintve, a Maros mente jelzi a gepida szállásterületet. Lehetséges, hogy Udvarhely megyéig is elöre hatoltak, talán épen az avar veszedelem elöl, s a régi adottságokat követve, Firtos várában huzódhatott meg egy csoportjuk (a III. térkép ez utóbbit nem tünteti fel). Erdély többi részéböl egyetlen leletünk sincsen sem e korból, sem a következö avarkorból. Ửgy látszik, a háromszéki medencét és a Barcaságot feladták, s az ojtozi út épenúgy bezárult, mint a többi keleti szoros. Erdély lakott területe, szinte a honfoglaláskor talált állapotáig zsugorodott össze. A keleti részek elhanyagolása nyilván annak következtében állott elö, hogy mind a gepidák, mind pedig az avarok észak, illetöleg nyugat felöl hatolnak az erdélyi medencébe. A hún uralom terjeszkedéséröl csak halvány nyomok állanak rendelkezésünkre, valószínủleg a gót és gepida területek politikai függőségén kívül számottevő hún népi elem nem jelent meg Erdéyben. Egy húnkori fejedelmi lelet, amely a Meszesi kapu környékén került elö, mindenesetre arra mutat, hogy a terület kézbentartása a Sziléziában s másutt megismert módon történt, nem pedig népi megszállás formájában. A kereskedelmi élet mindenképen óriási lendületet vesz a hún uralom alatt.

3. A z avarkor. Területe nagyjából a gepida szállásterületet fedi, csupán a Nagy- és Kisküküllő mentén található egy elöretolt ék egészen Korondig (mint említettem, lehetséges, hogy e terület már a gepidák alatt is meg volt szállva). Az erzsébetvárosi és a korondi préselőminták (mai értelemben $=$ gyárak), mindenesetre arra vallanak, hogy nagyobbszámú telepek ültek meg e területen. A Vöröstoronyi-szoros kézbevétele az avarság olténiai törekvéseivel magyarázható. Jelentösebb területgyarapodást figyelhetünk meg a Küküllök torkolata és a Vöröstoronyi-szoros közti területek benépesedésével. A sztrigymenti vidék megszállása is kétségtelen mu. tatója az avarkorban népi tömegeiben az Alföldre telepített gepidák birodalma teljes megszállásának. A keleti szorosok kikapcsolódása, mint már említettem, az erdélyi medencének nyugat felöl való megszállása mellett bizonyít; már az északról jövő gepidák alatt sem volt szerepük e kijáróknak.

4. A szlávok. Régészeti nyomaik igen szórványosak, jelenlétükre elsősorban helynévi emlékeik alapján következtethetünk. Valószínüleg az avarkorban jelennek meg Erdély területén s idevándorlásuk a nagyszabású avar telepítési mozgalommal függ össze. Elhelyezkedésük szempontjából igen tanulságos a térképvázlat; ebböl ugyanis nyilván látható, hogy a nép- 
vándorláskorban lakott területek peremén jelennek meg, illetöleg a gótok után néptelenül maradt területeket szállják meg. Úgy látszik tehát, hogy nemcsak a földrajzi tényezőknek (az aljnövényzet nélküli lomberdők perem területe) volt település-szabó erejük, hanem a szlávság elhelyezkedésének megértéséhez a népvándorláskor néptörténelmének ismerete is szükséges.

5. A magyar honfoglalás kora. A honfoglaló magyarság még a X. században megszállotta a teljes lakható Erdélyt, tehát az avar örökséget. $\mathrm{Ez}$ a tény világosan felismerhetö a III. térképen. Azt hiszem ennek a ténynek felismerését eddig két ok késleltette. Az első ok az, hogy csak sejtettük, de nem láthattuk tisztán Erdély földjének alakulását a népvándorlás korában. A második ok pedig az elsőböl következik: a kutatók elött több kevesebb tudatossággal a ma sürün lakott Erdély képe lebeghetett. A honfoglalás elözményeinek felismerése egyúttal a gyepük kérdésében is új lehetöségeket vethet fel. Erre később röviden utalok.

Az egyre gyarapodó székelyföldi honfoglaláskori leletek is új kérdéseket hoznak szönyegre. Az ojtozi út megszállása ma már alig vitatható, a székelyderzsi lelet pedig azt sejteti, hogy a nyugati és keleti szállásterület között a küküllömenti ösi úton megvolt a kapcsolat is. Egy Brassóban talált lelet, ha valóban honfoglaláskorinak bizonyul, a Barcaság korai megszállását jelenti.

IV. térkép. A II. és III. térkép adatainak egymásravetítése meggyőzö módon szemlélteti Erdély földjének fokozatos elnéptelenedését, s egyúttal kirajzolja Erdély településlehetőségeinek természetes erővonalait. Ebböl kitetszik, hogy a település megszabója, nem. a Marosvonal volt, mint eddig tanították, hanem az Ojtozi-szoroson betorkolló, a Küküllök mentén a Maroshoz vezető $\mathrm{s}$ ott két ágra szakadó út. Ennek egyik ága a Meszes-kapu felé tartott, a másik a Maros mentén vitt az Alföldre. Ez az út mintegy körülölelte a Bihari hegycsoport sohasem lakott tömbjét. A magyar honfoglalás' is ezen erővonalak mentén történt.

Megfigyelhetö, hogy az egymást váltó népek kivétel nélkül mindig megszállják a hódításuk pillanatában lakható terület teljes eröhálózatát, sőt nem egyszer, amint épen a gepida-avar-magyar időkben láttuk, a teljes lakható terület megszállására kerül sor. Igen nagyjelentőségü feladat lesz annak a tisztázása, hogy abban az esetben, ha csak az erövonalak megszállása következett be, mi történt az ott talált és ottmaradó néppel. Például igen tanulságos lenne ebböl a szempontból a római uralom alá sohasem került csíki dákság további sorsának tisztázása. Minket talán még jobban érdekel az udvarheìyi avarság sorsa. Hiszen erre a területre a magyarság csak a honfoglalás utáni században nyomul elöre.

A magyarság Erdélyben a honfoglaláskor még a lakható részekben is csak igen gyér lakósságot találhatott. Nyilván elsősorban a marosi és dési sóbányák vidékén volt csak elevenebb élet. A már említett szláv szórványokon kivül csak itt találhatolt jelentösebb számú lakosságra. E területek történeti adataink szerint bolgár megszállás alatt voltak. A bolgárságnak azonban egyelöre nem ismerjük régészeti nyomát Erdélyböl. Nem számítható ugyanis az e korbeli bolgársághoz az avar birodalom kutrigur rétegének hagyatéka.

Bár magam számára csak a Szent Istváni idökig szảndékoztam meg. 
kísérelni Erdély településtörténelmének felvázolását, nem térhetek ki a későbbi korok számára levonható tanulságok rövid ismertetése elöl sem. Ha rávezetjük az elnéptelenedést példázó térképre a magyarság XII. századi helyzetét, akkor szemléletes módon ismerhetjük fel azt, hogy Hunyad és Krassó-Szörény megyék területének kivételével a magyarság ebben a korban épen a vaskori határokig töltötte már ki az erdélyi medencét. Az a kevés, amit erről a folyamatról tudunk, sejteti, hogy a népi kitöltés az elnéptelenedés fordított sorrendjében, s a terjeszkedés az erdélyi föld megismert erővonalai mentén történt (vö. középkori megyéink hosszan kelet felé nyuló alakját). A magyarság tehát a XII. századig újból elérte a szkíták előtt lakott Erdély határvonalait. $\mathrm{Ez}$ a felismerés egyúttal nemzetiségeink betelepülésének és elhelyezkedésének kérdéséhez, tehát Erdély nemzetiségi képe keletkezésének logikájához is alapul szolgálhat. A további térhódítás soron következö területei ugyanis északon Beszterce környéke, délen pedig az Olt fogarasi és szebeni síkja lett volna. Az utóbbi terület gyér megszállása már kezdetét is vette. Természetesnek vehetö, hogy a betelepített szászok számára ezt a két területet jelölték ki Árpádházi királyaink, a magyarság pedig a két pólus között a csiki medence lassú kitöltésével folytatta a terület visszahódítását az ősrengetegtől és a mocsártól. A románságról is a déli lakatlan területekröl kapunk elöször okleveles híradást. Azon a részen tủnnek fel, amelyet feltünésük elött soha ember nem lakott. Ugyanígy soha semmiféle nyomát nem találtuk eddig az emberi életnek az Ilosvai hegységben s a Bihari hegycsoportnak abban a tömbjében, ahol a sorrendben következő oklevelek szerint a románság feltünik. A délnyugati hegyes részek is lakatlanoknak bizonyultak a rómaiság bukása utáni időkben. Ezek az erdő-benőtte hegységek ugyanis az őskortól Erdélyben Iakó egyetlen nép életmódjának sem feleltek meg. Sem a földművelő, sem a halászó-vadászó, de még a nomád állattartó-nép sem tudott semmit sem kezdeni ezekkel a területekkel. A leletek határvonala szinte évezredeken keresztül egységesen kikerüli tömbjüket. E hegyes erdöségek csak a hegyipásztor életformának szolgálnak talajul, s így természetes, hogy amikor feltünik a románság, akadálytalanul birtokba veheti Erdély e részeit. E nép érdeme az, hogy ezek a területek is beleilleszkednek Erdély emberföldrajzába.

\section{3.}

Térképvázlataim áttekintése és tanulságainak rövid ismertetése után még tovább szőhetem a bevezetésben felvetett módszertani kérdéseket. Nem szándékom egész hálózatuk felvázolása, hanem csak néhány pontban köz. löm jelentösebb tapasztalataimat.

1. Egy földfelület életesorának ilyen nagy távlatokban való vizsgálatakor a különbözö kor- és népi kérdések két, egymás rovására kiteljesedni igyekvő, élettani erö harcává egyszerüsödnek. A személytelenné vált emberi munka ugyanis ebben a távlatban nem az egyes ember vagy kor ilyen vagy amolyan elhatározását, akaratát, életformáját, stb. példázza, hanem az emberben levő biologikumot. Az ezzel szembefeszülö másik erö természetrajza mindenki elött világos, bár jó lenne a erdő térhódításának menetét közelebbröl szemügyre venni. Mihelyt azonban e nagy idö- és tér- 
beli távolságokat egy-egy korra, népre vagy életformára szükitjük, akkor a különleges adottságok sora színezi és teszi egyénivé ezt az idötlen küzdelmet. Mindebböl következik, hogy e folyamat megragadása és tisztázása csak akkor válik lehetségessé, ha jelenségeit a természettudományok könyörtelenül szigorú módszerességével írjuk le. Míg ez a munka meg nem történik, addig még a fenti nyers vázlat is túlnagy igényekkel lép fel az anyaggal szemben.

2. A fentiekböl következik, hogy egy kisebb területen lefolyó jelenségek helyes értékeléséhez csak akkor juthatunk el, ha a területet hatásterének környezetébe ágyazzuk. Erdélyt tehát az egész Kárpát-medence, sőt Közép-Európa erőhálózatában kell néznünk, egyes korokban pedig Észak- és Dél-Európáig, Spanyolországig és Belsö-Ázsiáig kell figyelemmel kísérnünk azokat az összetevöket, amelyekböl az itteni élet alakulását megérthetjük. E téren már igen jelentös elömunkálatokat végeztek el, de a fenti kívánalmak szerinti felméréshez e munka további terebélyesítése szükséges. Nem elegendő egy-egy kor szintjében elvégezni e munkát, hanem az azt megelöző korok s az öt követő idők függölegesébe is be kell ágyazni a vizsgált jelenséget.

3. A térképek elkészitésekor a következöképen igyekeztem eljárni: az egyes, kétségtelenül hiteles leletek körül egy bizonyos távolsággal húzott kört müvelödéstalajnak tekintettem. E területek nagyságának megállapításakor a gazdaságtörténelemnek a nagy számok törvényszerüségei alapján megállapitott megfigyeléseit tartottam szem elött. Ezekből a törvényekből ugyanis kisebb nagyobb ingadozásokkal kiderül, hogy egy-egy gazdasági rendszer mellett milyen terjedelmü föld szükséges az egyes ember eltartásához. A leletek helye köré tehát, a földfelszín adottságainak figyelembevételével, nagyobb területet kell rajzolnunk. Világos, hogy a civilizáció haladtával ezek a területek mind kisebbek és kisebbek lesznek, mert a föld eltartóképessége az eszközök tökéletesedése, a kereskedelem fejlödése, s más körülmények változása során egyre növekszik. Ennek következtében ugyanazon terület emberföldrajzi értékének megtartásához, de méginkább növeléséhez mind több és több ember jelenléte szükséges.

Ezeket az alapelveket térképvázlataim készítésekor nagyrészt épen a hasonló elömunkálatok hiánya miatt csak bizonyos fokig tudtam értékesiteni. Az egymástól távolabb esö területeken elökerült leleteket ilyen hozzávetöleges számítás alapján kapcsoltam egy területre, vagy hagytam meg elszigeteltségükben. E településtörténetileg igen jelentös tényezöket egyáltalán nem tudtam alkalmazni a laza határvonalakon belüli állapotok feltüntetésére. Ilyenképen le is mondottam erröl a kísérletröl; itt u. i. teljes részletességgel kellett volna a különbözỏ korok egymásváltó, vagy egymás mellett jelentkezỏ fínom rétegezödését megkülönböztetni. Ezt, a munka jelenlegi állása mellett, nem tudtam elvégezni. Térképeimen tehát az egyes korok laza határa nem jelenti egyúttal a határokon belül levö terület egyenletes sürüségü népi kitöltését. Meggyözödésem, hogy e kérdés kidolgozása további értékes mozzanatokkal hoz majd közelebb minket a vaskortól kezdődő elnéptelenedés erőjátékának megértéséhez.

Mivel nem volt módomban a területek pontosabb, de sok esetben még futólagos, bejárása sem, sok hiba történhetett azokon a heiyeken, ahol a 
nagy településtömbökön kivül esö leleteket a tömbökhöz kapcsoltam. Ilyen esetben a legpontosabb katonai térképnél is többet ér a terep bejárása. Magam részéröl azzal igyekeztem ezt a hibaforrást kiküszöbölni, hogy az elözö és következő korok e területre vonatkozó adatait figyelembe vettem.

E vázlatokban sok dolog maradt még tisztázatlanul. Nem csupán az elömunkálatok hiányos voltán múlott mindez, s nem is csak egyéni felkészültségem hiánya okozzák a vázlatok nyerseségét. Mindezeket több év munkájával többé-kevésbbé ki tudtam volna küszöbölni, vagy legalább is erősen csökkenthettem volna. Úgy éreztem azonban, hogy ez a munka nem egy ember munkája, hanem csak a kutatók céltudatos együttmüködése hozhat pontosabb eredményt. Ezért a munka iránti kötelességemnek tartottam vázlataim közlését, hogy a közlést természetszerüen követö megbeszélések, korrekturák folyamán közelebb juthassunk az egykori valóság szerkezetének és mozgató eröinek felismeréséhez. Nagyon is lehetséges tehát, hogy az egymástól függetlenül készitett térképeim egymásravetítése során tapasztalt törvényszerüségeket az újabb ásatások, újabban felvetödő szempontok módosítják, de azt hiszem, hogy alapjában véve e- nyers eredmények nagyjából megközelítik a dolgok egykori történésének logikáját.

A felvetődő sok kérdés közül néhánynak megemlítését nem mulaszthatom el. Kniezsa István Erdély hegyneveinek és folyóneveinek vizsgálatakor arra az eredményre jutott, hogy Erdély területe a honfoglaláskor csak igen gyéren lehetett megszállva, mert már a közepes nagyságú vizeink nevének nagyrésze is színmagyar, míg például Dunántúlon ezek legnagyobbrésze antik vagy népvándorláskori örökségböl való. A népvándorláskor erdélyi leleteinek térképezése teljes mértékben értelmezi Kniezsa eredményeit, mert csupán a nagy folyók mentén volt állandó lakosság, itt váltották egymást a népek, s adták át a nagy folyók neveit az utánuk jövőknek. A kisebb folyók vagy épen patakok mente a legtöbb esetben teljesen elnéptelnedett. Természetes tehát, hogy a magyar foglalók maguk nevezték el ezeket, s adták át e neveket másoknak akkor, ha e területen új nép váltotta fel őket. Ugyanez a helyzet a nemzetiségeink által lakatlanul talált területeken.

Mint említettem új kérdést vetnek fel a Székelyföldön talált honfoglaláskori leletek, különösképen ha e terület török helynévanyagát nézzük. Talán volt valami kapcsolat e helynévanyag és a határvédö törzsek (székelyek?) feltételezhető töröknyelvüsége között. Különösképen nö a leletek és nevek jelentösége annak tudatában, hogy — legalább is eddigi tudásunk szerint - e terület nem volt szerves része az avar birodalomnak, tehát a helynévanyag nem örizhet korábbi réteget.

A gepida-avar-magyar település a nyugati részeken szinte matematikai pontossággal fedi egymást (a dési magyar kiszögellés legkorábban Géza korában keletkezett!). Lehetséges, hogy e kérdés további tisztázása gyepürendszerünk keletkezéséhez is adatokkal szolgál. Nyilvánvaló ugyanis, hogy gyepüink erődítéseit nagyrészt készen találjuk. Feltevésemet egyelöre igy fogalmazhatnám meg: a magyarság Erdély elfoglalásakor a teljes lakható területet megszállja egészen az avar (?) gyepü-rendszerig.

Végezetül engedtessék meg. hogy egy olyan kérdést vessek fel, amely észszerüen következik a fenti eredményekböl, de amely a szigorúan vett tény- 
megállapító tudományos munkán túl már emberi értékrendszerünkbe torkollik. Meggyőzödésem ugyanis, hogy az a tényezö, amelyet a településben élettani erőként magyaráztam, egyúttal az egyes müveltségek és népek emberi értékének objektív értékméröje is. Kutatása az elözmények és következmények pontos ismeretében ugyanis minőségileg és mennyiségileg mérhető eredménnyel szolgál: az emberi munkával. Ha most ezzel a mérỏeszközzel fordulunk eredetileg felvetett kérdésemhez, hogy, t. i. milyen volt Erdély területe a honfoglaláskor, $\mathrm{s}$ mit végzett itt a magyarság a terület népi kitöltésével, akkor lehetetlen meg nem látni, hogy az a hallatlan erökifejtés, amellyel az akkor még alig földhöz szokott magyarság rövid 300 év alatt, a vaskortól kezdve egyre csökkenö s nyers tájjá változott területeket ismét az emberi müvelődés szolgálatába állította, nem mindennapi munka volt. Ezek az erdöírtó, földtúró magyarok soha el nem múló értékü munkát végeztek: az erdélyi medencét újból visszaadták az embernek. Ebböl a munkából késöbb a két keleti határterületen a szászság is részt kért, és sajátos életformájával nagy munkát végzett soha nem lakott területek bekapcsolásával a románság is. Erdély mai kulturtalajának munkájában tehát Erdély minden népe részt vett. A mennyiségi és minöségi munka azonban nem egyenlöképen oszlik meg közöttük. Nemzetiségeink későbbi terjeszkedése ugyanis már nem a nyers tájak felé történt; ők jórészt a magyar munka által már meghódított területre húzódtak. E terjeszkedés lehetőségének egyik föoka az volt, hogy Erdély erövonalait kezében tartó magyarság szenvedte a legnagyobb vérveszteséget az erövonalak mentén támadó ellenséggel szemben Erdély szabadságáért vívott harcaiban.

\section{IRODALOM}

Dolgozatom vázlatossága felment a részletes irodalmi utalások közlésétöl. Különösképen nem akarok elébevágni a népvándorlás- és honfoglalás közöletlen leletei feldolgozásának. A szövegben említett, forrásul szolgáló, munkák közül a legfontosabbakra a következỏkben utalhatok. Györffy István kunsági ásatásai még nem jelentek meg, Szabó Kálmán keeskemétkörnyéki középkori ásatásait a Magyar Nemzeti Múzeum adta ki (Az alföldi magyar nép mũvelõdéstörténeti emlékei. BiblHumHist. III. Bp. 1937), Pósta Béla gyulafehérvári és Roska Márton várfalvi és vajdahunyadi ásatásai a kolozsvári $\mathrm{D} \mathrm{olg} \mathrm{o} \mathrm{z} \mathrm{a} \mathrm{to} \mathrm{k}$ ban jelentek meg. Kovács István eddig csupán a Kolozsvár Zápolya-utcai honfoglaláskori temetôt közölte (Közle mények. Kolozsvár, 1942), míg a farkas-utcai templom kriptájának ásatásai még feldolgozásra várnak. Csalog József, Leszih Andor, Implom József, Méri István, Bálint Alajos és Domanovszky György középkori ásatásai a magyar kutatás erőteljesebb megindulását jelzik. A korai magyar idők erdélyi régészeti kérdéseire vö. László Gyula: A honfoglaló magyarság müvészete Erdélyben. ETI. Kolozsvár, 1943. Méri István kéziratos jelentésének eíme: Jelentés a Borsavölgy régészeti bejárásáról (ETI. Irattár, 1942). Az öskori leletekre vonatkozó adatokat, mint említettem, majdnem kivétel nélkül Roska Márton nagy munkájából merítettem (Erdély régészeti repertoriuma. I. Öskor), s térképezésükkor is a Repertorium térképmellékletei szolgáltak alapul, bár a lelöhelyek feltüntetése sok helyen nem történt pontosan. Erdély őskori 
életének vázolásakor igen nagy hasznát vettem Roska Márton számos részletmunkájának és összefoglaló jellegủ dolgozatainak. A római korra, különösképen pedig a limesre vonatkozó adatok térképre vitelekor a következő fontosabb munkák szolgáltak alapul: Torma Károly, Repertorium Dácia régiségés felirattani irodalmához. Bp., 1880. - Buday Árpád, Dolg. 1912:84. - Alföldi András, Századok, 1940:163. - Párduez Mihály, ArehÉrt. 1940:264 és 1942:313. Szilágyi János, Közl. 1943:88 (a nyugati limesre a legfontosabb!) Ferenezi István (Régészeti megfigyelések a limes dacicus északnyugati szakaszán. EM. 1941:189-214 és kny. Erd. Tud. Füz. 129. sz.), Paulovie; István (Dácia keleti határa és az ú. n. dák ezüstkincsek kérdése. ETI, Kv. 1943. Sajtó alatt). A esíki dák várakról Ferenezi Sándor munkája (Cetăti antiche în Judetul Ciuc 1936) és közöletlen ásatásairól kapott szíves felvilágosításai szolgáltak alapul. A Maros forrása menti gót településre a Székely Zoltán által közelebbröl közlendő tekerőpataki leletből (Folia V-VI, sajtó alatt) és közöletlen éremleletekböl következtettem. Kniezsa István megállapításaira vö: Magyarország népei a XI. században (Szt. István Emlékkönyv II. Bp. 1938. 367), Erdély földrajzi nevei (Erdély, Bp. 1940:71) és Erdély vínevei (ETI Évk. Kv. 1943 és kny.) címü munkáit. A földterület eltartóképességére vö: Schmoller (Grundriss. I, 183-Czettler-Szakâll: Bevezetés az egyetemes gazdaságtörténetbe. Bp., 1929. 65. l. alapján) fejtegetéseit. A népvándorlás és a magyar honfoglalás korának adattárát az előző irodalomból és a közöletlen leletek összeállításával magam végeztem el; segítségemre volt e munkában Roska Márton készségesen átengedett jegyzetanyaga is. E korok részletezését $\mathrm{s}$ a térképvázlat pontos indokolását egy későbbi munkámra tartom fenn. A XII. századi magyar határ és a szláv telepek hely-meghatározása Kniezsa Istvánnak a Szent István Emlékkönyvből már idézett dolgozatából való. A románokra vonatkozó évszámokat Fekete Nagy-Makkai oklevél-kiadványából vettem (Documenta historiam Valachorum in Hungaria illutrantia. Bp. 1941). 